Jurnal ABDIMAS INDEPENDEN

Vol. 1, No. 1, Mei 2020

\title{
PELATIHAN SISTEM APLIKASI KEUANGAN DESA
}

\author{
Intan Rakhmawati \\ Fakultas Ekonomi Dan Bisnis Universitas Mataram \\ intanrakhmawati@unram.ac.id \\ Baiq Rosyida Dwi Astuti \\ Fakultas Ekonomi Dan Bisnis Universitas Mataram \\ rosyidabaiq@unram.ac.id \\ Sapto Hendri BS \\ Fakultas Ekonomi Dan Bisnis Universitas Mataram \\ saptohendri99@unram.ac.id \\ Wirawan Suhaedi, SE., M.Ak. \\ Fakultas Ekonomi Dan Bisnis Universitas Mataram \\ wirawan.suhaedi@unram.ac.id
}

\begin{abstract}
ABSTRAK
Dana Desa dan Alokasi Dana Desa (ADD) diberikan dengan pemerintah desa sebagai Pelaksana Pengelola Keuangan Desa (PPKD) dengan kompleksnya peraturan dari berbagai kementerian. Dengan keluarnya Permendagri Nomor 20 Tahun 2018 yang menggantikan posisi bendahara dengan Kaur Keuangan sebagai pelaksana fungsi kebendaharaan, ditambah keluarnya Siskeudes V2.0 R.0.1, sehingga proses penatausahaan, pelaksanaan, hingga pelaporan Dana Desa dan Alokasi Dana Desa (ADD) menjadi semakin kompleks, karena bertambahnya jumlah dokumen, baik di penganggaran maupun pelaporan. Tidak hanya pembukuan dan pelaporan, Siskeudes juga mengcover aspek perpajakan dengan beragam pajak dari peraturan pusat maupun Peraturan Daerah (Peraturan Bupati). Oleh karena itu, hal ini menjadi rumit bagi PPKD. Pengabdian ini bertujuan memberikan pemahaman bagi anggota PPKD atas mekanisme sistem keuangan desa berdasarkan regulasi terbaru (termasuk pajaknya), hingga mekanisme Siskeudes V2.0 R.0.1. Metode pelaksanaan kegiatan pengabdian ini yaitu melalui sosialisasi, pelatihan, dan pendampingan, dengan subyek aparat pengelola keuangan Desa Gelangsar, Kecamatan Gunung Sari, Kabupaten Lombok Barat, dan pendamping desanya. Berdasarkan evaluasi kegiatan, pengabdian yang telah dilaksanakan cukup dapat memberikan pemahaman mekanisme sistem keuangan desa berdasarkan Permendagri Nomor 20 Tahun 2018, dan perbedaannya dengan Permendagri sebelumnya (Permendagri Nomor 113 Tahun 2014). Kegiatan pengabdian ini juga cukup dapat memberikan petunjuk penggunaan dan pengoperasian Siskeudes V2.0 R.0.1, hingga jenis dan cara input pajak atas setiap belanja desa.
\end{abstract}

Kata Kunci: Pengelolaan Keuangan Desa, Aplikasi Keuangan 


\section{PENDAHULUAN}

\section{Analisis Situasi}

Adanya Dana Desa (DD) dan Alokasi Dana Desa (ADD) yang dikendalikan oleh 3 kementerian, yaitu Kementerian Desa, Pembangunan Daerah Tertinggal, dan Transmigrasi (Kementerian Desa dan PDTT), Kementerian Keuangan, dan Kementerian Dalam Negeri, telah memberikan kesempatan bagi desa untuk mengurus tata pemerintahan sendiri, termasuk di dalamnya pengelolaan keuangan hingga pelaporan melalui Siskeudes. Namun penerapan banyaknya peraturan dari berbagai kementerian menghadapi kendala teknis, antara lain kebingungan para aparat Pelaksana Pengelolaan Keuangan Desa (selanjutnya disingkat PPKD), atas mekanisme penetapan penggunaan Dana Desa dan Alokasi Dana Desa, pelaksanaan, hingga pelaporan atas realisasinya. Terlebih kini sudah keluar Permendagri Nomor 20 Tahun 2018 yang ditambah keluarnya Siskeudes V2.0 R.0.1, dengan adanya penambahan jumlah dokumen, baik di penganggaran maupun pelaporan.

Atas kompleksnya hal-hal ini, walaupun ada tenaga pendamping desa, 1 orang pendamping desa seringkali harus menangani beberapa desa sekaligus. Padahal walaupun desa-desa tersbeut berada di kecamatan yang sama, namun dengan karakteristik desa dengan aparat pengelola keuangan desa PPKD yang berbeda, merupakan hal yang kompleks juga bagi pendamping desa.

Tidak hanya pembukuan dan pelaporan, Siskeudes juga mengcover aspek perpajakan dalam pengelolaan keuangan desa. Terlebih lagi, pajak yang harus dibayar tidak hanya mencakup 1 jenis pajak saja seperti Pajak Penghasilan (PPh), namun juga pajak mencakup pajak atas belanja (termasuk belanja modal), atas pendapatan yang harus diterima, maupun atas jasa dan sewa yang dilakukan. Pajak ini tidak hanya dikendalikan oleh peraturan pusat, namun juga Peraturan Daerah (Perda) yang berbeda-beda pada setiap kabupaten. Oleh karena itu, hal ini menjadi cukup rumit bagi PPKD. 


\section{Jurnal ABDIMAS INDEPENDEN}

Vol. 1, No. 1, Mei 2020

Sasaran kegiatan ini adalah para anggota PPKD di Desa Gelangsar, Kecamatan Gunung Sari yang terdiri dari kepala desa, sekretaris, kaur keuangan, bendahara desa, hingga pendamping desanya. Kegiatan dilakukan melalui pelatihan sistem keuangan desa, pelatihan penggunaan Siskeudes V2.0 R.0.1, serta pelatihan penghitungan pajak atas dana desa, dengan tujuan peningkatan pemahaman atas mekanisme sistem keuangan desa (dan perbedaannya dengan Permendagri Nomor 113 Tahun 2014), serta inputnya dalam Siskeudes V2.0 R.0.1. Melalui kegiatan ini, para anggota PPKD diharapkan mampu melakukan penatausahaan hingga pelaporan secara efisien, agar dapat menyampaikan laporan keuangan tepat waktu.

\section{METODE KEGIATAN}

Kegiatan pengabdian ini dilakukan melalui sosialisasi dan pelatihan peraturan keuangan desa, pengoperasian Siskeudes V2.0 R.0.1, serta peraturan perpajakan. Permasalahan di lokasi pengabdian sudah diawali dari 2018, dimana pada 2018, yang antara lain disebabkan oleh penggunaan SISKEUDES versi baru saat itu (Siskeudes. Setelah pengabdian 2018, masalah ini sudah tidak terjadi atas Siskeudes lama (Siskeudes V1.0.R1.06.), namun karena penggunaan Siskeudes baru (Siskeudes V2.0 R.0.1), pelatihan teknis penggunaan Sisekudes dan pembuatan dokumen (karena adanya juga penambahan jumlah dokumen, baik di penganggaran maupun pelaporan) menjadi perlu dilakukan kembali. Materi tahapan-tahapan dalam pengelolaan keuangan desa yang dibahas meliputi :

a. Pelatihan sistem keuangan desa (dari tahap Perencanaan, Pelaksanaan, Penatausahaan, Pelaporan, dan Pertanggungjawaban).

b. Pajak atas keuangan desa.

c. Pembahasan permasalahan dalam penggunaan Siskeudes V2.0 R.0.1, serta solusinya. 
Untuk menunjang kelancaran kegiatan ini, Tim PPM melakukan koordinasi dengan pihak-pihak terkait yaitu : Lembaga Penjaminan Mutu dan Pengembangan Pendidikan (LPMP2) Universitas Mataram, Dekan Fakultas Ekonomi Universitas Mataram, serta Kepala Desa di Desa Gelangsar, Kecamatan Gunung Sari. Evaluasi keberhasilan kegiatan ini dilihat dari kehadiran, respons, dan pertanyaan dari pengelola keuangan desa pada saat pelatihan dilaksanakan.

\section{HASIL DAN PEMBAHASAN}

Pelatihan sistem aplikasi keuangan desa bertempat di Desa Gelangsar, Kecamatan Gunung Sari. Peserta yang diundang adalah Kepala Desa, Sekretaris Desa, Kaur Keuangan, tokoh desa, dan BUMDes. Materi yang diberikan tentang tahapan pengelolaan keuangan dana desa, dokumen-dokumen yang dibutuhkan, serta penatausahaannya di Siskeudes menurut Permendagri No.20 Tahun 2018 (Siskeudes .

Materi tahapan-tahapan dalam pengelolaan keuangan desa yang dibahas meliputi : (a) Perencanaan; (b) Pelaksanaan; (c) Penatausahaan; (d) Pelaporan; dan (e) Pertanggungjawaban. Fitur-fitur dalam aplikasi Siskeudes bertambah karena basis yang digunakan saat ini sudah berubah menjadi basis kas.

Selain itu, materi tentang tarif pajak juga dibahas dalam kegiatan ini. Pelatihan ini juga dipadukan dengan diskusi atas kasus yang terjadi pada Desa Gelangsar, Kecamatan Gunung Sari atas semua pajak, mulai dari Pajak Penghasilan Pasal 21, Pasal 22, Pasal 23, Pasal 4 ayat 2, serta Pajak Pertambahan Nilai (PPN), hingga pajak kabupaten. Atas transaksi tersebut, Tim Pengabdian menjelaskan bagaimana menghitung nilai pajaknya, serta bagaimana mencatatnya dalam Siskeudes.

Secara garis besar, berikut perubahan dokumen dan proses dalam Siskeudes. 


\section{Jurnal ABDIMAS INDEPENDEN}

Vol. 1, No. 1, Mei 2020

a. Dalam versi 2019 , pada menu perintah di Pelaporan dan Penganggaran, terdapat total 13 perintah dengan 4 penambahan menu perintah yang terdiri dari :

$\checkmark$ RAK- Rencana Anggaran Kas Desa

$\checkmark$ RAK- Rencana Kegiatan dan Anggaran

$\checkmark$ DPA-Rencana Kegiatan Desa

$\checkmark$ DPA- Kegiatan Lanjutan.

b. Menu Rekening APBDesa digunakan untuk melakukan pengelolaan data Rekening APBDesa. Pengguna aplikasi tidak diperbolehkan melakukan perubahan kode Akun, Kelompok dan Jenis. Hal ini disebabkan karena level 1 s.d 3 telah diatur dalam Permendagri Nomor 113 Tahun 2014 tentang Pengelolaan Keuangan Desa. Penambahan dan pengubahan kode rekening pada level 4 mengacu pada Peraturan Bupati/Kepala Daerah yang mengatur tentang Pengelolaan Keuangan Desa.

c. Penambahan kode rekening belanja modal diselaraskan dengan kode aset tetap atau disesuaikan dengan peraturan yang mengatur tentang kekayaan milik desa. Dengan kodifikasi yang selaras, proses belanja modal langsung dapat dikonversi dalam Laporan Kekayaan Milik Desa.

d. Adanya pemecahan menjadi kegiatan dan menjadi paket mulai dari tahap perencanaan, serta adanya pula standar satuan harga. Parameter standar satuan harga digunakan untuk memasukkan data standar harga yang dijadikan acuan bagi desa pada saat menyusun APBDesa. Untuk mempermudah implementasi data standar harga dibuat pada masingmasing obyek belanja. Data standar harga diisi oleh administrator Kabupaten/Kota sesuai dengan harga yang berlaku di Kabupaten/Kota setempat. Oleh karena itu, besaran harga satuan tidak dikunci pada saat penginputan data $R A B$.

Berikut gambar kegiatan pelatihan tersebut: 


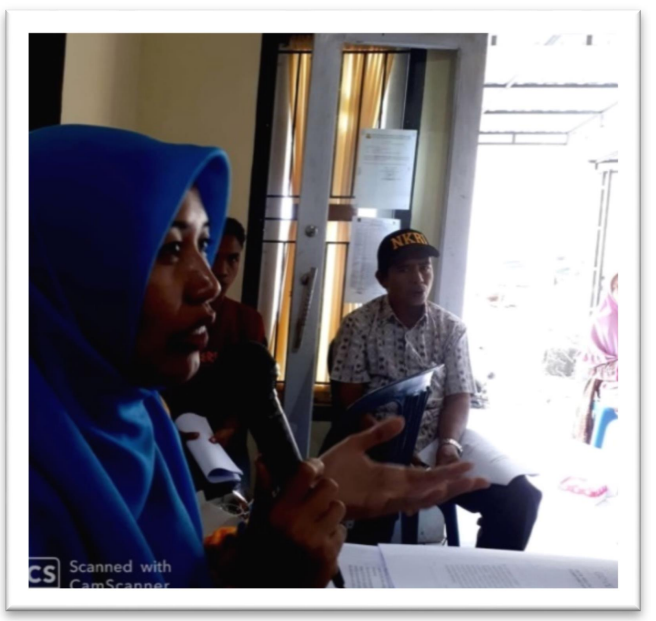

Gambar 1. Pelatihan Pengelolaan Keuangan Desa

e. Kode pemotongan dan penyetoran pajak dengan akun yang dimulai 7.x.x.xx tidak perlu diubah karena berhubungan dengan akun 2.x.x.x pada akun utang pajak di Neraca. Kode tersebut di dalamnya terdapat nomor Mata Akun Pajak (MAP). Untuk melakukan input pajak pada Siskeudes ini, lakukan sebagaimana halnya Siskeudes sebelumnya, SPP definitif atau panjar dibuat terlebih dahulu, kemudian dibuat dokumen penyetorannya di aplikasi pajak bendahara. Jika sudah berhasil diinput, maka akan mendapatkan kode ID Billing.

Berikut gambar pelatihan pajak atas keuangan desa:

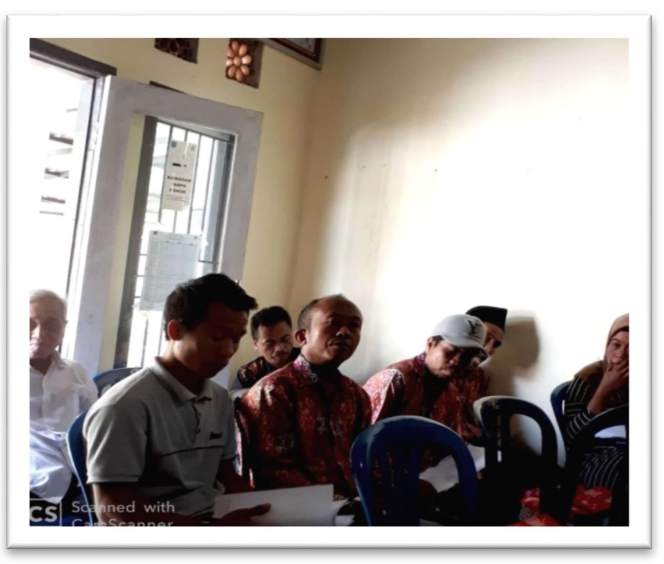

Gambar 2. Pelatihan Pajak atas Keuangan Desa 


\section{Jurnal ABDIMAS INDEPENDEN}

Vol. 1, No. 1, Mei 2020

f. Menu Pelaporan mencakup:

$\checkmark$ Laporan Realisasi Anggaran Desa;

$\checkmark$ Laporan Realisasi Anggaran Desa per Kegiatan;

$\checkmark$ Laporan Realisasi Anggaran Desa Periodik (bulanan, triwulanan dan semesteran);

$\checkmark$ Laporan Kekayaan Milik Desa;

$\checkmark$ Laporan Realisasi Anggaran per Sumber Dana;

$\checkmark$ Laporan Realisasi Penggunaan Dana Desa; dan

$\checkmark$ Laporan Penyerapan Dana Desa PMK 225.

g. Laporan pertanggungjawaban desa meliputi:

$\checkmark$ Laporan Realisasi APBDes;

$\checkmark$ Laporan Realisasi Kegiatan;

$\checkmark$ Kegiatan yang belum selesai dan/atau tidak terlaksana; dan

$\checkmark$ Sisa Anggaran

\section{KESIMPULAN DAN SARAN}

Berdasarkan evaluasi kegiatan, pengabdian yang telah dilaksanakan cukup dapat memberikan pemahaman mekanisme sistem keuangan desa berdasarkan Permendagri Nomor 20 Tahun 2018, dan perbedaannya dengan Permendagri Nomor 113 Tahun 2014. Kegiatan pengabdian ini juga cukup dapat memberikan petunjuk penggunaan dan pengoperasian Siskeudes V2.0 R.0.1 hingga pengoperasian input perpajakannya dalam proses penatausahaan dan penyusunan laporan keuangan desa.

\section{DAFTAR PUSTAKA}

Direktorat Jenderal Pajak Kementerian Keuangan Republik Indonesia. UndangUndang Nomor 36 Tahun 2008 tentang Perubahan Keempat atas UndangUndang Nomor 7 Tahun 1983 Tentang Pajak Penghasilan. Jakarta: Direktorat Jenderal Pajak Kementerian Keuangan Republik Indonesia. 
. Undang-Undang Nomor 42 Tahun 2009 tentang Perubahan Ketiga atas Undang-Undang Nomor 8 Tahun 1983 Tentang Pajak Pertambahan Nilai Barang dan Jasa dan Pajak Penjualan atas Barang Mewah. Jakarta: Direktorat Jenderal Pajak Kementerian Keuangan Republik Indonesia.

- Peraturan Direktur Jenderal Pajak Nomor PER16/PJ/2016 Tentang Pedoman Teknis Tata Cara Pemotongan, Penyetoran, dan Pelaporan Pajak Penghasilan Pasal 21 dan/atau Pajak Penghasilan Pasal 26 Sehubungan dengan Pekerjaan, Jasa, dan Kegiatan Orang Pribadi. Jakarta: Direktorat Jenderal Pajak Kementerian Keuangan Republik Indonesia.

Kementerian Dalam Negeri Republik Indonesia. 2014. Peraturan Menteri Dalam Negeri Nomor 113 Tahun 2014 tentang Pengelolaan Keuangan Desa. Jakarta: Kementerian Dalam Negeri Republik Indonesia.

. 2014. Peraturan Menteri Dalam Negeri Nomor 114

Tahun 2014 tentang Pedoman Pembangunan Desa. Jakarta: Kementerian Dalam Negeri Republik Indonesia.

2018. Peraturan Menteri Dalam Negeri Nomor 20

Tahun 2018 tentang Pengelolaan Keuangan Desa. Jakarta: Kementerian Dalam Negeri Republik Indonesia.

Kementerian Desa, Pembangunan Daerah Tertinggal, dan Transmigrasi. Peraturan Menteri Desa, Pembangunan Daerah Tertinggal, dan Transmigrasi Nomor 19 Tahun 2017 Tentang Penetapan Prioritas Penggunaan Dana Desa Tahun 2018. Jakarta: Peraturan Menteri Desa, Pembangunan Daerah Tertinggal, dan Transmigrasi.

Suhaedi, Wirawan, Baiq Rosyida Dwi Astuti, dan Intan Rakhmawati. 2016. Evaluasi Pengelolaan Keuangan Desa. Laporan Penelitian, Fakultas Ekonomi dan Bisnis Universitas Mataram, Tidak Dipublikasikan.

Atikah, Siti, Sapto Hendri BS, Intan Rakhmawati. 2018. Model Implementasi Akuntansi dan Pelaporan Keuangan Desa. Laporan Penelitian, Fakultas Ekonomi dan Bisnis Universitas Mataram, Tidak Dipublikasikan.

Badan Pengawasan Keuangan dan Pembangunan. Modul Pengelolaan Keuangan Desa \# 4 Modul Aplikasi Sistem Keuangan Desa (SISKEUDES). Jakarta: Deputi Bidang Pengawasan Penyelenggaraan Keuangan Daerah, 2016. 


\section{Jurnal ABDIMAS INDEPENDEN}

Vol. 1, No. 1, Mei 2020

Sistem Keuangan Desa (SISKEUDES) Manual Operasi

Aplikasi SISKEUDES 2.0. Jakarta: Deputi Bidang Pengawasan

Penyelenggaraan Keuangan Daerah, 2018. 